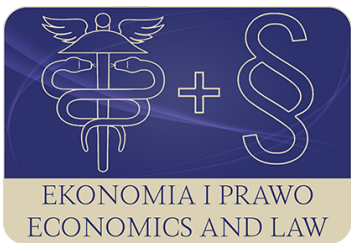

EKONOMIA I PRAWO. ECONOMICS AND LAW

Volume 19, Issue 2, June 2020

p-ISSN 1898-2255, e-ISSN 2392-1625

www.economicsandlaw.pl

ORIGINAL ARTICLE

received 20.11.2019; revised 16.01.2020; accepted 30.06.2020

Citation: Huterski, R., \& Kaz, E. (2020). Corporate Social Responsibility indices for shares listed

on the Warsaw and Moscow stock exchanges: design limitations of information value for socially responsible investors. Ekonomia i Prawo. Economics and Law, 19(2): 261-273. doi:10.12775/EiP.2020.018.

\title{
Corporate Social Responsibility indices for shares listed on the Warsaw and Moscow stock exchanges: design limitations of information value for socially responsible investors
}

\author{
ROBERT HUTERSKI \\ corresponding author \\ Nicolaus Copernicus University in Torun, Faculty of Economics and Management, Department \\ of Digital Economy and Finance, ul. Gagarina 13a, 87-100 Toruń, Poland \\ $\square$ robhuski@umk.pl \\ (D) orcid.org/0000-0001-9821-7176 \\ EVGENIYA KAZ \\ National Research Tomsk State University, Institute of Economics and Management, Russian \\ Federation \\ घk123a@mail.ru \\ orcid.org/0000-0002-5913-9248
}

\begin{abstract}
Motivation: Investors often do not have the opportunity to assess how much a company is responsible for its relationships with employees, the environment, and consumers. This is not due to the fact that there are no socially responsible companies in Russia and Poland, but it is connected with low informational transparency about the activities of companies and low awareness of socially responsible investment. Well-designed CSR/ESG index-

es can over time increase interest in socially responsible investing in stock exchanges and have a positive impact on more pro-social and pro-environmental behaviour of companies.

Aim: The aim of the article is to evaluate the construction of the CSR/ESG indices of the Warsaw and Moscow stock exchanges from the point of view of their information
\end{abstract}


value for socially responsible investors with particular consideration given to coefficients of correlation with main indices and to coefficients of variation.

Results: The RESPECT, MRRT and MRSV indices constructions are dominated by the criteria of company selection like in the main indices and they do not give sufficient recognition to the achievements of the companies in the field of CSR. Building rankings that clearly differentiate companies in terms of the degree of their achievement of objectives of CSR is undoubtedly influenced by subjectivism in the selection of evaluated features and their importance. However, copying the set of companies from elementary indices to CSR ones seems unsuitable as it leads to very strong correlations between those indices, which makes them unattractive for investors when compared with the main ones.

Keywords: socially responsible investment; stock indices; CSR; ESG JEL: Al3; G11; G41; M14; Q56

\section{Introduction}

The idea of Corporate Social Responsibility (CSR) as well as the concept of environmental, social and corporate governance (ESG), which followed, are already reflected in the activities of all more important stock exchanges in the world. In order to support socially responsible investing, special indices of listed companies were developed, whose aim is to help investors to put money into shares of companies meeting the standards of CSR/ESG.

The aim of the article is to evaluate the construction of the CSR/ESG indices of the Warsaw and Moscow stock exchanges from the point of view of their information value for socially responsible investors with particular consideration given to coefficients of correlation with main indices and to coefficients of variation. CSR/ESG indices useful for investors should differ noticeably from main indices, both in terms of the set of companies and index quotations. CSR/ ESG indices useful for investors should differ noticeably from basic indices, both in terms of the set of companies and index quotations.

The CSR/ESG indexes described in the article differ in design and period of operation on the stock exchange, therefore their assessment against the background of main indexes may generate additional conclusions.

As for Russia, the main motives for putting into practice the strategy of socially responsible investment are the inner convictions of the entrepreneurs themselves, the need to enter the world market, administrative pressure, the influence of competitors, etc. (Savina, 2016).

In addition, investors often do not have the opportunity to assess how much a company is responsible for its relationships with employees, the environment, and consumers. This is not due to the fact that there are no socially responsible companies in Russia, but it is connected with low informational transparency about the activities of companies and low awareness of SRI. Finally, the society shows insufficient attention to the social, environmental and ethical aspects of the activities of Russian companies, and, therefore, there is no such interest among companies themselves (Kabir, 2017). 
However, as soon as a company needs to enter an IPO, moving to international reporting standards, it undertakes additional efforts to improve the practice of corporate management, to increase its transparency through the publication of non-financial reporting, etc. (Demirbag et al., 2017).

Due to the impact of the aforementioned limitations, corporate social responsibility indices for shares listed on the Moscow Stock Exchange were started only recently, that is on lst April 2019 (MOEX-RSPP Responsibility and Transparency Index, short name MRRT and MOEX-RSPP Sustainability Vector Index, short name MRSV). However, the awareness of the need for promoting socially responsible investing existed in the Russian business much earlier. For that reason, the Russian Union of Industrialists and Entrepreneurs (RSPP \& MOEX, 2019) supported the calculation of this type of indices since as early as the end of 2014, many years before they became official indices of the stock exchange, and this fact is reflected in the names of the indexes.

As far as Poland is concerned, the problems with the development of socially responsible investing indicated in the source literature have showed a strong similarity to the ones in Russia described above (Doś \& Foltyn-Zarychta, 2016, pp. 653-663).

The index of socially responsible companies called RESPECT, which has been operating on the Warsaw Stock Exchange since 19th November 2009, until 2013 allowed investors to build portfolios delivering returns considerably higher than the market average with an acceptable level of risk (Lulewicz-Sas \& Kilon, 2014). However, it did not contribute to an intense development of SRI in Poland. The period of time from 2016 to 2019 has manifested general stagnation on the WSE main market despite a good economic situation in the country (WSE, 2019b).

It is significant that while in Moscow an important step towards promoting SRI by starting MRRT and MRSV indices has been taken, the Warsaw stock exchange started the publication of the new WIG-ESG index on 3rd September 2019. It is a total return index taking account of proceeds from dividend and pre-emptive rights. The WIG-ESG index includes the biggest companies listed on the regulated market of the Warsaw Stock Exchange S.A. which are the WIG20 and mWIG40 indices participants as at the end of July in a given year. The weights of companies in the index, like in the case of other indices, depend on the number of the free-floating shares corrected basing on the ESG ranking prepared by Sustainalytics company and on the evaluation of applying the rules of Good practices of companies listed on the WSE 2016. The WIG-ESG will constitute the underlying assets for the passive fund managed by NN Investment Partners TFI (WSE, 2019d).

In the WSE's opinion, its current RESPECT index has implemented its educational assumptions for the 10 years of its functioning. Together with the initiation of the publication of the WIG-ESG index, an index with a very strong investment profile was started. Until the end of 2019, WSE will publish both WIG-ESG index and the RESPECT Index, and from January 2020 only 
the WIG-ESG. It is strong evidence for the growing importance of ecological aspects in indices created for the needs of socially responsible investing (WSE, 2019a). It also reaffirms the need to monitor investment suitability of the CSR/ ESG indices and of periodical correcting of their construction.

Due to the short period of time in which the WIG-ESG has been functioning, the RESPECT index constitutes the base for the analyses in the article. It will allow drawing conclusions which could be useful in future comparisons of the RESPECT and WIG-ESG functioning. In this article, the conclusions will be used to verify the construction of new when it comes to their exchange seniority Moscow CSR/ESG indices.

\section{Literature review}

Modern concepts of corporate social responsibility state that when making a business decision, owners and managers of the company must answer not only the question whether it is good for business, but also the question whether it is good for the environment and society. We owe this definition of the meaning of the company to the concept of socially responsible business, which began to form in the second half of the XX century in the USA, UK, Japan and Germany. Since then corporate social responsibility has been defined as the expectations of society towards owners and management, production structures, on the one hand, and their awareness of their duty to the society, the collective, and the individual for their actions and social consequences, on the other hand (Bowen, 1953; Drucker, 1954; Frederick, 2006).

Thus, according to the supporters of the concept of social responsibility, socially responsible investing gains importance as also economic and not only ethical category, motivating corporations to conduct socially responsible policies in terms of economic benefits.

A number of studies by Edmans (2011), Kempf \& Osthoff (2007) prove that a portfolio consisting of the 100 best companies to work for (the best employers) significantly outperforms a comparable base portfolio.

Therefore, to support socially responsible investing (SRI), a number of indices have been developed in the world that include the shares of companies selected as a result of their activities in accordance with the criteria of corporate social responsibility (Mikołajek-Gocejna, 2018).

Statman (2006) examined the composition of four socially responsible indices and compared them to the composition of the conventional S\&P500 index. The mean social scores of the socially responsible indices differed, and indices varied in the emphasis they place on particular characteristics, but the mean score of each was higher than the score of the S\&P 500.

A similar conclusion is drawn by Savina (2016), who analyse an average yield (over a three-year period) and the yield of major ethical funds S\&P and reveal that the yield of ethical funds exceeds the yield of $S \& P$ by nearly 2.5 times. She further concludes that "with full confidence, we can conclude the positive 
dynamics of development of socially responsible investments in the post-crisis period'.

Eccles et al. (2014) analyse firms with sustainable practices in 1993 over the time period from 1993 to 2009 . They show that these firms follow different practices and have a different investor base and thus have a higher stock performance than their counterparts with a lower sustainability performance. Edmans (2011) reveals positive abnormal returns between 1984 and 2005 for a portfolio of the 100 Best companies to work for in America and concludes that certain SRI screens may increase stock returns.

Bebchuk et al. (2013) report positive abnormal stock returns for SRI portfolios from 1990 to 1999. Similarly, Borgers et al. (2013) consider SRI portfolios on the basis of KLD data (MSCI KLD 400 Social Index - one of the first Socially Responsible Investing indices launched in 1990) and find that these have a higher stock performance from 1992 to 2004, but that the abnormal returns are insignificant in the following years.

Badia et al. (2019) proves that over the period from 2005 to 2014, SRI portfolios statistically outperform the conventional investments. During bear market periods, the financial performance is neutral for both portfolios, whereas during bull market periods, SRI portfolios statistically outperform the conventional investment.

Vanwalleghem (2017) notes that 'SRI screening limits the amount of risk diversification in the market for shunned firms causing traditional investors to demand an additional risk premium'.

However, the opponents of SRI are sceptical whether CSR confers meaningful benefits on companies and, even if such benefits can be shown to be present, they do not translate into better financial performance. At best, according to the opponents, there are no financial advantages to corporate social responsibility. Some opponents of SRI would go one step further: companies pursuing CSR will actually perform worse because such efforts will distract management from their key focus - maximizing profits.

Baumol (1991) concludes that 'similarly, when competition in a product market is intense, CSR sacrifices profits, which is not possible. Thus, CSR is not feasible in a competitive economy'.

Nelling \& Webb (2009) find a weak correlation between the measures of corporate social responsibility and financial performance. Moreover, their analysis suggests that high corporate social performance is driven by rather than drives high financial performance. That is, firms engage in CSR because they have the necessary financial resources rather than because it will boost their financial performance.

The Royal Bank of Canada makes a conclusion, based on a solid literature review, that 'socially responsible investing does not result in lower investment returns. This is an important finding because it provides support to individual investors and trustees of institutional funds that they can pursue a program of socially responsible investing with the expectation that investment returns 
will be similar to traditional investment options' (RBC, 2012). This conclusion is confirmed in the new, updated and extended edition of the paper, but in a relaxed form: 'socially responsible investment does not necessarily result in lower investment returns, the question of whether socially responsible investment strategies outperform traditional investment strategies remains inconclusive' (RBC, 2019).

\section{Methods}

In the research described in the article, ratings of stock market indices from the Warsaw Stock Exchange (WSE) and the Moscow Exchange (MOEX) were used. For comparative purposes, both the ratings of stock market indices of socially responsible companies (CSR) and of basic stock indices were used.

From WSE, they are RESPECT as CSR index and basic price indices WIG20, mWIG40, SWIG80 and their total return equivalents, that is WIG20_TR, mWIG40_TR, SWIG80_TR. 2429 observations from the period from 31st December 2009 to 18th September 2019 were taken into consideration. From MOEX they are MRRT and MRSV as CSR indices and IMOEX and RTSI as basic indices. 121 observations from the period of 1st April to 19th September 2019

For the dependency between the aforementioned indices, correlation coefficients were calculated and their significance was checked using z-statistics (1):

$$
Z=\frac{r_{x y}}{\sqrt{1-r_{x y}^{2}}} \cdot \sqrt{n},
$$

because of a large sample. For evaluating the Risk connected with investing in portfolios based on these indices, coefficients of variation (CV) of indices ratings were also calculated.

\section{Results}

Polish and Russian CSR/ESG indices are supposed to play the same role; however, RESPECT is created according to a completely different procedure than MRRT and MRSV, because it includes companies from three functioning stock indices (WIG20, MWIG40, sWIG80), not from the list of companies (Kołosowska \& Huterska, 2013, pp. 176-185). As early as during the selection of companies, the transparency of reporting is taken into account in the creation of the RESPECT and there is no index in Poland equivalent to the MRRT. As a result, RESPECT is closer to MRSV index, but not quite comparable. At the time of writing this article, RESPECT index has been functioning for more than 10 years (since 19.11.2009), but MRRT and MRSV indices only for several months (since 01.04.2019).

The calculations of correlation coefficients conducted for selected indices of the Warsaw stock exchange and the Moscow stock exchange separately 
and calculations of the coefficients of variation indicated interesting features of the relationship between both CSR indices and elementary indices, and in the case of the Warsaw stock exchange, between elementary price indices and total return ones.

On the correlations described below, the z-statistics prove that all calculated correlations for Warsaw and Moscow indices are statistically significant (i.e., the null hypothesis about the irrelevance of the correlation coefficient at the significance level of $\alpha=0.05$ is rejected).

RESPECT index is the total revenue index (TR, income together with dividend payments), and MRRT and MRSV are price indices. Dividends are significant, as evidenced by the low correlation of RESPECT with WIG20 (the price-weighted index of large companies, 0.1755), and a very high correlation with its total return version WIG20TR (0.8970). What is more, mWIG40 (and mWIG40_TR) and sWIG80 (and sWIG80_TR) have a negative correlation with WIG20, but not with WIG20_TR. If dividends were not of practical importance, there would be no such differences in correlations.

However, on the other hand, noticeable difference in correlation between the price and the total return version of the index (weaker correlation, more significant impact of dividend in TR versions) is visible for large companies (WIG20 vs. WIG20_TR, 0.4461) compared to medium and small ones (mWIG40 vs. mWIG40_TR, 0.9911 and sWIG80 vs. sWIG80_TR, 0.9522). See the correlation matrix (table 1 and table 2).

In addition, the volatility (coefficient of variation, CV) of total revenue indices is higher than of the price indices and interestingly, the mWIG40 midsized companies index has noticeably greater volatility, not only than the large companies index (WIG20), but also the small companies index (sWIG80). The same can be observed also for both the price and TR versions of these indices (table 3).

When it comes to the CSR indices of the MRRT Moscow stock exchange (Responsibility and Transparency) and MRSV (Sustainable Development Vector), it should be remembered that together with IMOEX and RTSI, they are price indices (this group does not include total return ones).

A mutual correlation between MRRT and MRSV and their correlations with elementary indices are unusually strong (table 4 ). All the six coefficients of correlation exceed 0.85 and four of them 0.90 . The strongest, almost full correlation exists between MRRT and IMOEX, the main index of the Moscow stock exchange (0.9925).

The biggest coefficient of variation of the examined Moscow indices concerns RTSI index, which is denominated in US dollars, which results in it being significantly influenced by the fluctuations between the Russian ruble to the American dollar. MRSV index appears to be the most stable one in this group (table 5). Generally, all the four examined indices of the Moscow stock exchange manifest significantly higher coefficients of variation than the examined indices of the Warsaw stock exchange, both the price and the total return ones, with 
one exception. Only the variation of MRSV is smaller that of mWIG40_TR, which is however a total return index (of mid-sized companies).

\section{Conclusion}

The analysis of the functioning of the companies in the Warsaw Stock Exchange RESPECT index guided by social responsibility principles, taking into account its transformation into WIG-ESG index, enables interesting conclusions concerning its equivalents on the Moscow Stock Exchange, MRRT and MRSV indices, to be drawn.

RESPECT index is the total revenue index (TR, income together with dividend payments), and MRRT and MRSV are price indices. All the Warsaw elementary total return indices manifest a higher coefficient of variation than that of the price indices. Taking into account dividend payments enables investors to have a more realistic overview of the financial activity of the companies than the share prices themselves especially when a company is evaluated according to the CSR/ESG criteria.

The mWIG40 mid-sized companies index has noticeably greater volatility than not only the large companies index (WIG20), but also the small companies index (sWIG80). The same can be observed also for both the price and TR versions of these indices. On the one hand, a greater index volatility is associated with a higher investment risk, but on the other hand, it means the possibility an increased profitability of investments. This, together with the meaning of midsized companies for the economy, makes them an attractive element of the RESPECT Index portfolio.

When it comes to the CSR indices of the Moscow Stock Exchange, MRRT (Responsibility and Transparency) and MRSV (Sustainable Development Vector), it should be remembered that together with IMOEX and RTSI, they are price indices. MRSV index appears to be the most stable one in this Moscow group, but when compared with MRRT, it can result from a smaller number of companies included in the index (15 and 22 respectively), most of which can be found in both indices.

The conducted calculations indicated a strong correlation between the main stock exchange index dominated by the shares of big companies (WIG20_TR) and the RESPECT Index on the Warsaw Stock Exchange. On the Moscow Stock Exchange all the correlations of the main IMOEX and RTSI indices with MRRT and MRSV indices and inside pairs of indices of the same type are equally strong or stronger.

On both of the stock exchanges, though to a greater degree on the Moscow one, it results from two closely connected basic reasons: 1) the selection of companies for CSR indices is dominated by the weight of the market capitalization despite the regulated limitations of the participation of big companies in the index, 2) the CSR indices construction does not does not take adequate account of the differences between the companies when it comes to their involvement 
in CSR regardless the size of the equity capital. In conclusion, the RESPECT, MRRT and MRSV indices constructions are dominated by the criteria of company selection like in the main indices and they do not give sufficient recognition to the achievements of the companies in the field of CRS. Building rankings that clearly differentiate companies in terms of the degree of their achievement of objectives of CSR is undoubtedly influenced by subjectivism in the selection of evaluated features and their importance. However, copying the set of companies from elementary indices to CSR ones seems unsuitable as it leads to very strong correlations between those indices, which makes them unattractive for investors when compared with the main ones.

The forthcoming replacement of the RESPECT Index by WIG-ESG on the Warsaw Stock Exchange at the end of 2019 indicates the same line of thinking of its authorities. The RESPECT Index has played its educational role and the time has come for an index of an investment character. The now index is still a total return one, a single and universal one, and it underlines the ecological issues not just in its name. The weights of the WIG-ESG companies depend on the number of the free-float shares corrected with the results of the ESG ranking prepared by the Sustainalytics company and with the evaluation of the use of the corporate governance principles formulated by WSE.

Comparing to the experiences of the WSE, a proposition can be made for the Moscow Stock Exchange to create a new ESG shares index functioning alongside the current MRRT and MRSV indices or even instead of them. This time the new index would be a single total return, and not a price one taking into account a bigger number of companies with more exposed ecological aspects that the two existing ones and to a more degree reflecting the rankings of social achievements of individual companies than the capital weight of their shares on the stock exchange, but also encouraging to create new stock exchange products on its basis.

The Warsaw Stock Exchange is reforming its social responsibility index after 10 years of its functioning, and the Moscow CSR indices have existed on the stock exchange for less than a year. However, assuming that its authorities will accept the need of the existence of the CSR/ESG indices truly alternative to the main indices, they will critically evaluate the MRRT and MRSV indices and will skillfully use the experiences and reforms of the foreign stock exchanges. Just like the WSE has done, the MRRT and MRSV indices can be treated as educational ones, preparing companies and investors for a new true CSR/ESG index with its own clear character when compared with the IMOEX and RTSI main indices.

\section{References}

Badia, G., Ferruz, L., \& Cortez, M.C. (2019). The performance of socially responsible stock portfolios: international evidence. Paper presented at the EFMA European Financial Management Association 2019 Annual Meeting, Azores. Retrieved 10.11.2019 from https://efmaefm.org. 
Baumol, W. (1991). Perfect markets and easy virtue: business ethics and the invisible hand. Cambridge: Blackwell.

Bebchuk, L.A., Cohen, A., \& Wang, C.C. (2013). Learning and the disappearing association between governance and returns. Journal of Financial Economics, 108(2). doi:10.1016/j.jfineco.2012.10.004.

Borgers, A., Derwall, J., Koedijk, K., \& ter Host, J. (2013). Stakeholder relations and stock returns: on errors in investors' expectations and learning. Journal of Empirical Finance, 22. doi:10.1016/j.jempfin.2013.04.003.

Bowen, H. (1953). Social responsibilities of the businessman. New York: Harper.

Demirbag, M., Wood, G., Makhmadshoev, D., \& Rymkevich, O. (2017). Varieties of CSR: institutions and socially responsible behaviour. International Business Review, 26(6). doi:10.1016/j.ibusrev.2017.03.011.

Doś, A., \& Foltyn-Zarychta, M. (2016). Socially responsible investment market size in Poland: the content analysis. In D. Prochazka (Ed.), New trends in finance and accounting: proceedings of the 17th Annual Conference on Finance and Accounting. Cham: Springer. doi:10.1007/978-3-319-49559-0_60.

Drucker, P.F. (1954). The practice of management. New York: Collins.

Eccles, R.G., Ioannou, I., \& Serafeim, G. (2014). The impact of corporate sustainability on organizational processes and performance. Management Science, 60(11). doi:10.1287/mnsc.2014.1984.

Edmans, A. (2011). Does the stock market fully value intangibles?: employee satisfaction and equity prices. Journal of Financial Economics, 101(3). doi:10.1016/j.jfineco.2011.03.021.

Frederick, W.C. (2006). Corporation, be good!: the story of corporate social responsibility. Indianapolis: Dog Ear Publishing.

Kabir, L.S. (2017). Socially responsible investing: a trend or a temporary phenomenon? Economics, Taxes \& Law, 10(4).

Kempf, A., \& Osthoff, P. (2007). The effect of socially responsible investing on portfolio performance. European Financial Management, 13(5). doi:10.1111/j.1468-036X.2007.00402.x.

Kołosowska, B., \& Huterska, A. (2013). Wpływ działań społecznie odpowiedzialnych na redukcję kosztów operacyjnych na przykładzie wybranych spółek giełdowych należących do RESPECT index. Prace Naukowe Uniwersytetu Ekonomicznego we Wroctawiu, 297.

Lulewicz-Sas A., Kilon J. (2014). Analysis of the effectiveness of socially responsible investment funds in Poland. Economics \& Management, 19(4). doi:10.5755/j01.em.19.4.8101.

Mikołajek-Gocejna, M. (2018). The environmental, social and governance aspects of social responsibility indices: a comparative analysis of European SRI indices. Comparative Economic Research, 21(3). doi:10.2478/cer-2018-0017.

Nelling, E., \& Webb, E. (2009). Corporate social responsibility and financial performance: the virtuous circle revisited. Review of Quantitative Finance and Accounting, 32(2). doi:10.1007/s11156-008-0090-y. 
RBC. (2012). Does socially responsible investing hurt investment returns? Retrieved 10.11.2019 from https://mafiadoc.com.

RBC. (2019). Does socially responsible investing hurt investment returns? Retrieved 10.11.2019 from https: / /www.rbcgam.com.

RSPP \& MOEX. (2019). Sustainability indices: 2018 highlights. Retrieved 10.11.2019 from http://media.rspp.ru.

Savina, T.N. (2016). Socially responsible investing: theory and methodology of research. Financial Analytics: Science and Experience, 9(15).

Statman, M. (2006). Sociable responsible indexes: composition, performance, and tracking error. The Journal of Portfolio Management, 32(3). doi:10.3905/ jpm.2006.628411.

Vanwalleghem, D. (2017). The real effects of sustainable \& responsible investing. Economics Letters, 156. doi:10.1016/j.econlet.2017.04.008.

WSE. (2019a). GPW launches the WIG-ESG Index. Retrieved 10.11.2019 from https://www.gpw.pl.

WSE. (2019b). Report of the management board on the activity of the parent entity and the Gietda Papierów Wartościowych w Warszawie Group in 2018. Retrieved 10.11.2019 from https://www.gpw.pl.

WSE. (2019c). Retrieved 12.02.2020 from https://www.gpw.pl.

WSE. (2019d). Uchwata Nr 804/2019 Zarządu Gietdy Papierów Wartościowych w Warszawie S.A. z dnia 12 sierpnia 2019 r. w sprawie szczegótowych zasad konstrukcji i podawania do publicznej wiadomości indeksu WIG-ESG: annex. Retrieved 10.11.2019 from https://www.gpw.pl.

\section{Acknowledgements}

Author contributions: authors have given an approval to the final version of the article. Authors contributed to this work as follows: R.H. and E.K. developed the concept and designed the study, R.H. collected the data, R.H. analysed and interpreted the data, R.H. and E.K. prepared draft of article, R.H. and E.K. revised the article critically for important intellectual content.

Funding: this research was undertaken as part of the Russian Foundation for Basic Research, Research project no. 18-010-0034 Business Models of Companies as the Basis for the Formation of Common Values and Social Capital and was fully funded by its grant. 


\section{Appendix}

Table 1.

Warsaw Stock Exchange indices: correlation coefficients

\begin{tabular}{lcccc}
\hline \multirow{2}{*}{ CSR index } & \multicolumn{3}{c}{ Price weighted main indices } \\
\cline { 2 - 4 } & RESPECT & WIG20 & mWIG40 & sWIG80 \\
\hline RESPECT & 1.0000 & 0.1755 & 0.8025 & 0.5575 \\
WIG20 & & 1.0000 & -0.1894 & -0.0670 \\
mWIG40 & & 1.0000 & 0.7953 \\
sWIG80 & & & 1.0000 \\
\hline
\end{tabular}

Notes:

Using the observations 31.12.2009-18.09.2019, 5\% critical value (two-tailed) for $n=2429$.

Source: Own preparation based on WSE (2019c).

Table 2.

Warsaw Stock Exchange indices: correlation coefficients

\begin{tabular}{|c|c|c|c|c|}
\hline \multirow{2}{*}{ CSR index } & \multicolumn{4}{|c|}{ Total revenue (TR) main indices } \\
\hline & RESPECT & WIG20_TR & mWIG40_TR & sWIG80_TR \\
\hline RESPECT & 1.0000 & 0.8970 & 0.7866 & 0.6772 \\
\hline WIG20 & & 0.4461 & -0.2361 & -0.1862 \\
\hline mWIG40 & & 0.7007 & 0.9911 & 0.9309 \\
\hline sWIG80 & & 0.4402 & 0.7215 & 0.9522 \\
\hline WIG20_TR & & 1.0000 & 0.6988 & 0.5619 \\
\hline mWIG40_TR & & & 1.0000 & 0.8913 \\
\hline sWIG80_TR & & & & 1.0000 \\
\hline
\end{tabular}

Notes:

Using the observations 31.12.2009-18.09.2019, 5\% critical value (two-tailed) for $n=2429$.

Source: Own preparation based on WSE (2019c).

Table 3.

Warsaw Stock Exchange indices: coefficients of variation (CV)

\begin{tabular}{lclc}
\hline \multicolumn{1}{c}{ Price indices } & \multicolumn{1}{c}{ CV } & Total Revenue indexes & CV \\
\hline- & - & RESPECT & 0.1474 \\
WIG20 & 0.1058 & WIG20_TR & 0.1169 \\
mWIG40 & 0.2401 & mWIG40_TR & 0.3031 \\
sWIG80 & 0.1444 & sWIG80_TR & 0.1735 \\
\hline
\end{tabular}

Notes:

Using the observations 31.12.2009-18.09.2019, for $n=2429$.

Source: Own preparation based on WSE (2019c). 
Table 4.

Moscow Exchange Indices: correlation coefficients

\begin{tabular}{lcccc}
\hline \multirow{2}{*}{ Indices } & \multicolumn{2}{c}{ CSR indices } & \multicolumn{2}{c}{ Main indices } \\
\cline { 2 - 5 } & MRRT & MRSV & IMOEX & RTSI \\
\hline MRRT & 1.0000 & 0.8515 & 0.9925 & 0.9101 \\
MRSV & & 1.0000 & 0.8771 & 0.9530 \\
IMOEX & & 1.0000 & 0.9266 \\
RTSI & & & 1.0000 \\
\hline
\end{tabular}

Notes:

Using the observations 01.04.2019-19.09.2019, 5\% critical value (two-tailed) for $n=121$.

Source: Own preparation based on WSE (2019c).

Table 5.

Moscow Exchange indices: coefficients of variation (CV)

\begin{tabular}{|c|c|}
\hline Price indices & $\mathrm{CV}$ \\
\hline MRRT & 0.0361 \\
\hline MRSV & 0.0268 \\
\hline IMOEX & 0.0352 \\
\hline RTSI & 0.0434 \\
\hline
\end{tabular}

Notes:

Using the observations 01.04.2019-19.09.2019 for $n=121$.

Source: Own preparation based on WSE (2019c). 
